\title{
EVALUASI SAMBUNGAN MUR-BAUT STRUKTUR PORTAL TRUSS “THE GREAT HALL” OBI ECO CAMPUS - JATILUHUR
}

\author{
${ }^{1}$ Kenny Christian. ${ }^{2}$ Anastasia Maurina, S.T., M.T. \\ ${ }^{1}$ Student in the Bachelor's (S-1) Study Program in Architecture \\ at Parahyangan Catholic University \\ ${ }^{2}$ Senior lecturer in the Bachelor's (S-1) Study Program in Architecture \\ at Parahyangan Catholic University
}

\begin{abstract}
Bolt joint is one of the common joineries in a modern bamboo construction. The usage of the bolt joints in bamboo joinery are believed to be the most efficient therefore the bolt joint was used regardless of the various kind of different forces in every bamboo joinery. One of the disadvantage of the bolt joints in bamboo construction in the force that flow parallel to the bamboo fibers therefore some of joineries needed to be strengthen to prevent the joinery failure. The Great Hall OBI Eco Campus is one of the building which the joineries entirely connected by the bolt joints, through different forces in every joinery some of the joinery in the building are strengthen by rope. The bolt joints have many other combinations to strengthen the joinery that could be an option, they are bolt joint with clamping and with mortar injection.
\end{abstract}

Key Words: Bolt Joint, parallel forcee to the bamboo fiber, strengthen by rope, "The Great Hall" OBI Eco Campus, Clamping, Mortar Injection

\section{CONNECTION OF BOLT JOINTS PORTAL TRUSS STRUCTURE'S EVALUATION "THE GREAT HALL" OBI ECO CAMPUS - JATILUHUR}

\author{
${ }^{1}$ Kenny Christian. ${ }^{2}$ Anastasia Maurina, S.T., M.T. \\ ${ }^{1}$ Mahasiswa S1 Program Studi Arsitektur Universitas Katolik Parahyangan. \\ ${ }^{2}$ Dosen Pembimbing S1 Program Studi Arsitektur Universitas Katolik Parahyangan
}

\begin{abstract}
Abstrak- Mur-baut merupakan penyambung batang bambu yang pada bangunan berkonstruksi bambu modern. Penggunaan mur-baut pada sambungan bambu diyakini sebagai sambungan bambu yang paling efektif, akibatnya bangunan bambu secara keseluruhan menggunakan sambungan mur-baut tanpa memperhatikan gaya-gaya yang terjadi pada tiap-tiap sambungan padahal sambungan mur-baut sangat lemah terhadap gaya sejajar serat bambu. Objek penelitian yaitu "The Great Hall" OBI Eco Campus merupakan salah satu bangunan seluruhnya menggunakan sambungan mur-baut. Akibat gaya-gaya yang berbeda pada tiap-tiap sambungan maka ada beberapa sambungan yang memerlukan pengikatan. Pengikatan dilakukan pada bangunan "The Great Hall" OBI Eco Campus dilakukan pada sambungan-sambungan yang memiliki gaya sejajar serat bambu. Perkuatan yang dilakukan untuk upaya menguragi kerusakan sejajar bambu pada sambungan mur-baut memiliki kombinasi lainnya yang dapat dijadikan pertimbangan yaitu sambungan dengan klem maupun dengan pengecoran.
\end{abstract}

Kata Kunci: Mur-Baut, gaya sejajar serat bambu, pengikatan, “The Great Hall” OBI Eco Campus, Klem, Pengecoran

\section{PENDAHULUAN}

\footnotetext{
${ }^{1}$ Corresponding Author: k.hardjani@gmail.com
} 
Bambu merupakan sebuah material yang terdapat di seluruh dunia, di area tropis maupun sub-tropis. Sejarah penggunaan bambu sebagai sebuah material bangunan sudah ada sejak peradaban manusia dimana bambu sudah ada. Bambu merupakan sebuah material yang cukup mudah untuk dikerjakan, material bambu pada bangunan dapat digunakan sebagai bahan untuk membuat struktur bangunan, dinding, lantai, hingga atap.

Bambu sebagai sebuah material bangunan memiliki beberapa kelemahan, kelemahan utama pada material bambu terletak pada lemahnya bamboo terhadap serangga, jamur, dan bakteri pengurai. Menurut Janssen (2000), bambu hanya dapat bertahan 10-15 tanpa pengawetan sehingga material bambu tentu saja kalah kuat dengan material bangunan yang lainnya seperti kayu, bata, dan beton. Karena kekurangan-kekurangan dari material bambu tersebut maka bambu dikenal sebagai "Kayu untuk orang miskin" dan hanya digunakan untuk bangunan orang kelas ekonomi yang rendah dan bangunan yang tidak permanen. Pada masyarakat dengan ekonomi yang lebih mapan material bambu diganti dengan material lain yang lebih bertahan lama.

Akibat kemampuan bertahan dari material bambu yang sangat lemah maka penelitian akan hubungan sambungan bambu menjadi sedikit, sehingga bangunan yang memiliki material menjadi sedikit dan tidak bervariatif dibandingkan bangunan yang berkonstruksi kayu.

Seiring perkembangan jaman dengan teknologi yang semakin berkembang dan keadaan dunia yang mendesak untuk mengkonservasi energi, beton dan kayu sudah diyakini sebagai material yang tidak ramah lingkungan sehingga bambu menjadi masa depan dari material bangunan. Bambu merupakan sebuah material yang sangat ramah energi, dalam kurun waktu 3 tahun bambu sudah dapat menjadi sebuah struktur bangunan yang kuat dan bambu juga memliki kekuatan yang memiliki skala berat dan kekuatan yang sama dengan baja.

Dengan berkembangnya teknologi dan penelitian, material bambu kini dapat dibuat menjadi material yang lebih tahan lama dari sebelumnya. Dengan berkembanganya material bambu menjadi sebuah material yang lebih durable, Kini konstruksi material bambu dapat ditemukan pada rumah, jembatan, dan bangunan publik. Tujuan utama dari penggunaan bambu pada bangunan-bangunan tersebut untuk memaksimalkan penggunaan material yang cepat dan mudah diregenerasikan pada alam dan menghindari material-material yang memakan energi yang besar. Oleh karena itu penelitian mengenai sambungan bambu sangatlah dibutuhkan untuk memperbesar cangkupan penggunaan material bambu.

\section{KAJIAN TEORI}

Penggunaan sambungan mur baut pada bambu yang dahulu digunakan sebagai sambungan yang digunakan pada kontruksi bangunan kayu memungkinkan material bambu untuk membuat bangunan berkontruksi lebih besar dibandingkan sambungan bambu yang tradisional seperti ikat, dan yang lainnya. Dengan sistem yang lebih modern yang diterapkan pada material bambu memungkinkan material bambu untuk membentuk kolom yang lebih besar dan bentang yang lebih besar. Karakter dari sambungan-sambungan ini mampu memberikan material bambu kesan estetis yang baru dan spesifik. 


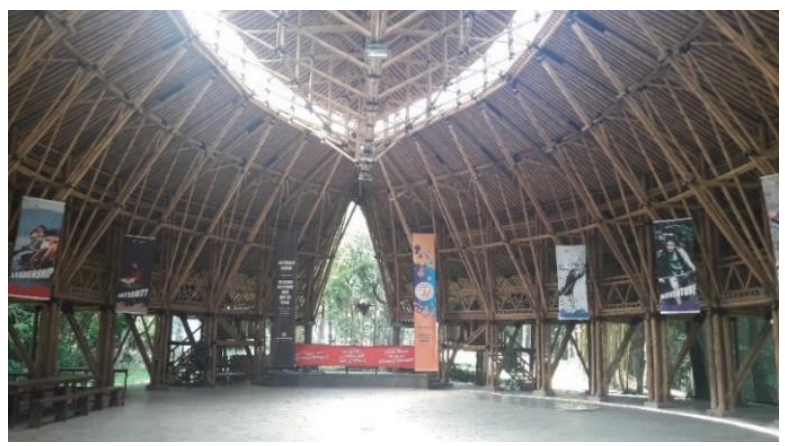

Figur 1. Interior "The Great Hall" OBI Eco Campus

Bangunan OBI (Outward Bound Indo) Campus merupakan salah satu bangunan berkonstruksi bambu yang terdapat di Indonesia. Sambungan-sambungan yang terdapat pada konstruksi bambu pada bangunan ini hamper semua menggunakan Mur Baut sebagai alat penyambungnya.

Sambungan Mur Baut merupakan salah satu sambungan paling banyak ditemui pada bangunan berkonstruksi bambu modern. Sambungan Mur Baut memungkinkan bangunan berkonstruksi bambu untuk memikul beban yang berat. OBI Campus merupakan salah satu bangunan berkonstruksi bambu yang memiliki sistem sambungan Mur Baut pada hampIr seluruh sambungannya. Beberapa pertanyaan yang muncul pada perumusan masalah ini adalah (1) Bagaimana perilaku gaya dan potensi kerusakan pada tiap-tiap sambungan mur-baut yang terdapat pada struktur portal truss bangunan? (2) Bagaimanakah upaya yang dapat dilakukan pada sambungan mur-baut untuk memperkecil potensi kerusakan pada sambungan?

\section{METODA PENELITIAN}

Metode penelitian yang dilakukan bersifat deskriptif dan eksperimental. Pengkajian kualitatif dari sambungan-sambungan ini di dahului oleh studi literatur dari kajian mengenai klasifikasi jenis sambungan. Sambungan-sambungan yang telah diklarifikasikan tersebut dianalisis berdasarkan gaya-gaya yang terjadi pada sambungan tersebut sehingga didapatkan potensi kegagalan dari sambungan tersebut. Kombinasi sambungan yang lain dibuat melalui eksperimen mur-baut dan kombinasinya sebagai perbandingan dari sambungan mur-baut yang sudah ada. Sambungan-sambungan tersebut kemudian dilakukan tes kekuatan untuk mengetahui sambungan mana yang paling optimal untuk menerima gaya-gaya yang terjadi.

Variabel-variabel yang akan diteliti keterkaitannya satu sama lain adalah (1) Jenis sambungan; (2) Gaya yang terjadi pada tiap sambungan; (3) Kerusakan pada tiap-tiap sambungan; (4) Pertimbangan kombinasi sambungan.

\section{ANALISA \\ 4.1 DATA OBJEK PENELITIAN}




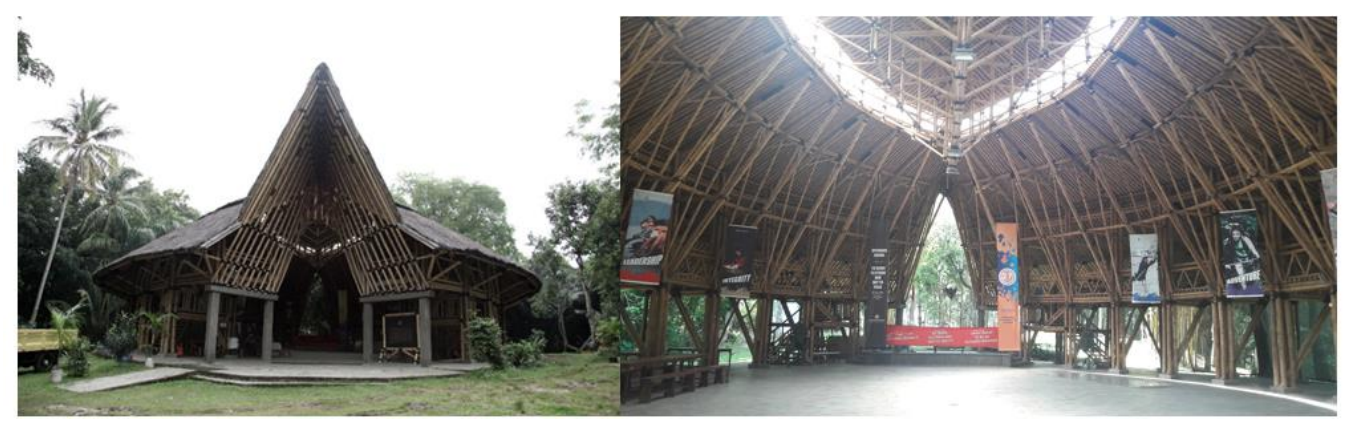

Figur 2. Entrance Bangunan OBI Campus

(Sumber : ketukangan.wordpress.com dan dokumentasi pribadi)

\section{STRUKTUR "THE GREAT HALL"}

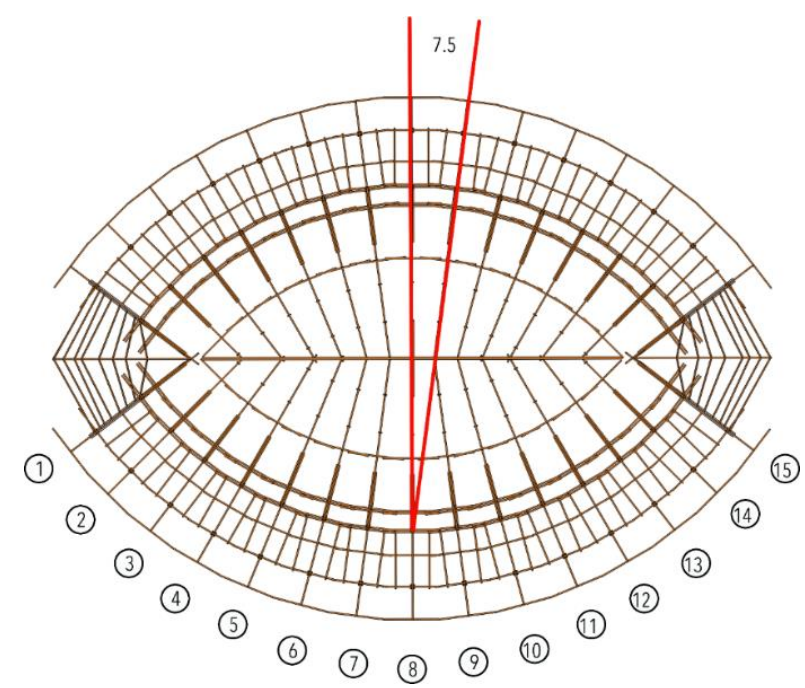

Figur 3. Denah OBI Campus
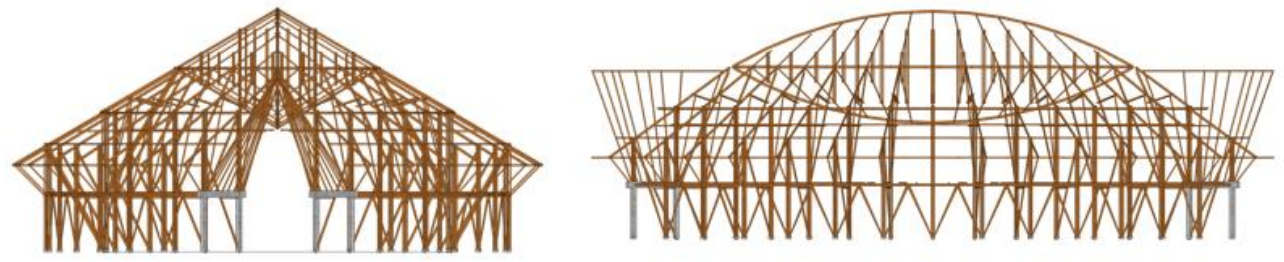

Figur 4. Tampak Depan dan Tampak Samping

"The Great Hall" OBI Campus merupakan sebuah bangunan bentang besar berkonstruksi bambu. Bentang terpanjang dari bangunan ini sepanjang 20 meter dari kolom terdalam dan 26 meter apabila dihitung dari kolom terluar. Bangunan ini juga memiliki tinggi 18 meter. Pola lengkung pemasangan tiap struktur portal didapat dari letak pusat lingkaran dengan sudut 7.5 derajat. 


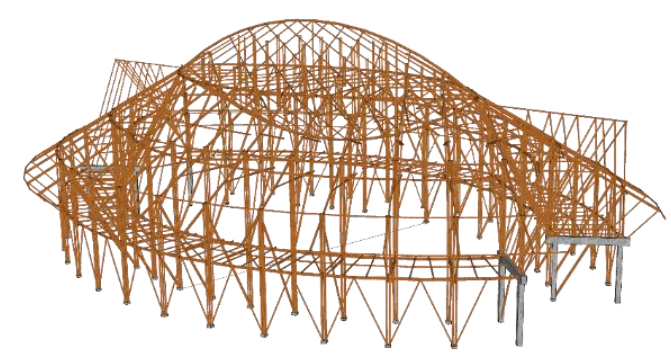

Figur 4. Perspektif

Pada bangunan ini terdapat lantai mezzanine yang mengelilingi bangunan. Lantai mezzanine pada banguna ini terbetuk di dalam rangka struktur portal bangunan. Struktur portal pada bangunan memikul mahkota bangunan yang memiliki skylight disekitar mahkota bangunan tersebut. Pada bagian depan bangunan terdapat bentuk atap yang berbeda dari atap struktur portal utama bangunan. Struktur atap ini menyerupai bentuk kapal pada bagian depan.
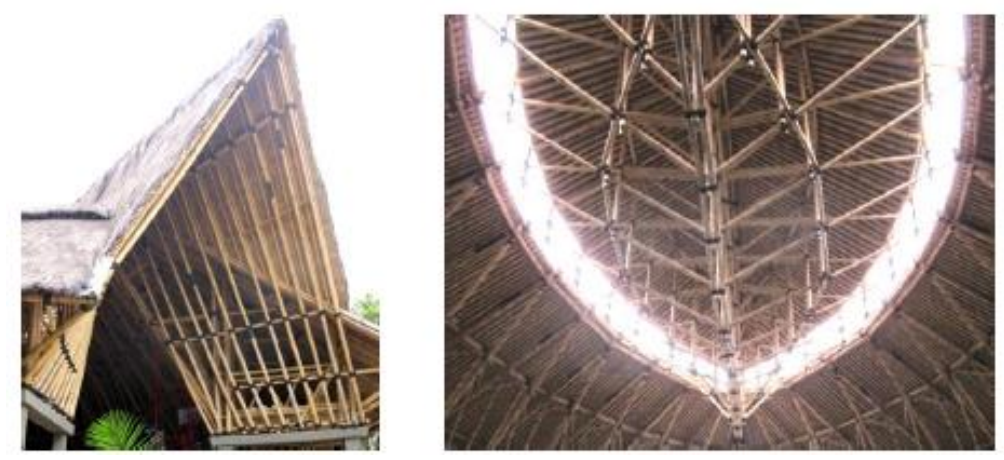

Figur 5. Eksterior dan Interior Bangunan

\section{Sistem Struktur Bangunan OBI Campus}

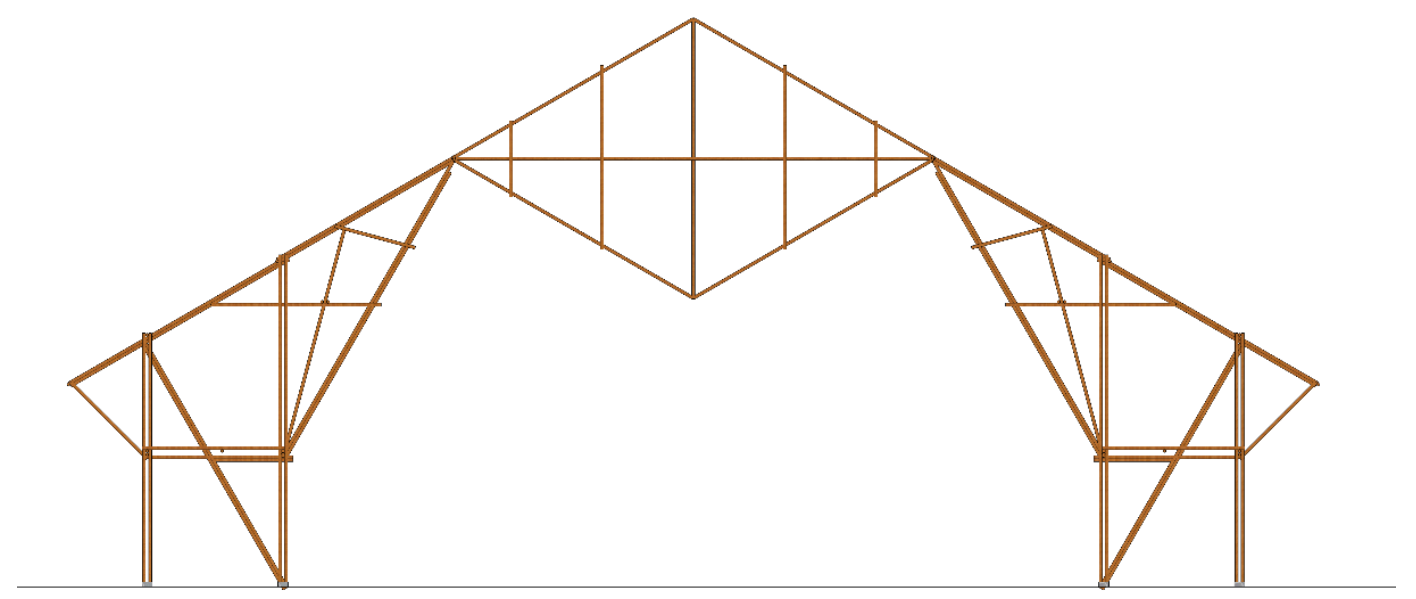

Figur 6. Struktur Trussed Portal Frame bangunan OBI Campus 
Bedasarkan jenis struktur strukturnya bangunan OBI Campus ini dapat digolongkan menjadi struktur Trussed Portal Frame. Bangunan ini memiliki 15 buah kolom pada tiap sisinya.

Akibat jenis struktur bangunannya yang merupakan Trussed Portal Frame, bangunan ini memiliki sambungan jepit pada batang horizontal dan batang vertikalnya. Penyaluran beban pada bangunan ini merupakan aksial-tranversal sehingga momen terdapat pada kedua struktur vertical maupun horizontal.

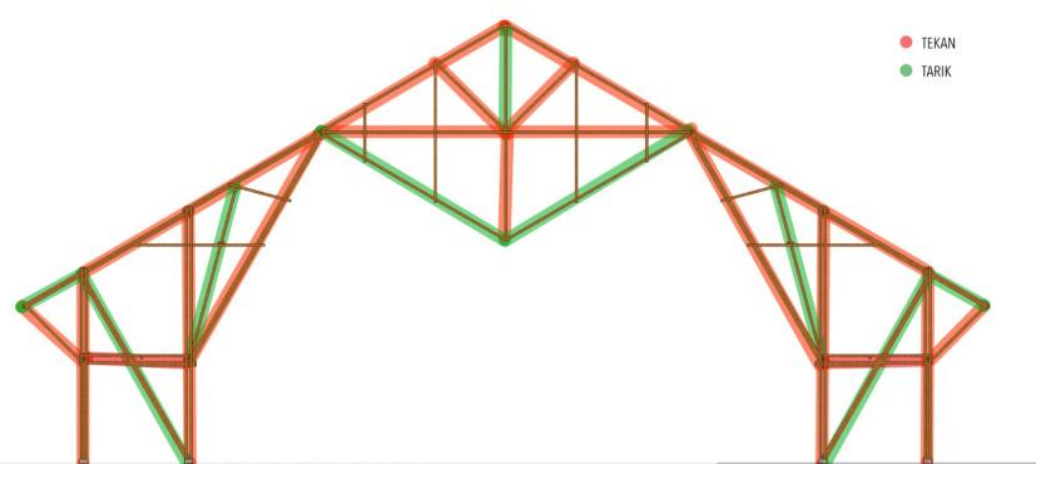

Figur 7. Diagram Tekan dan Tarik Batang Struktur Utama

Data hasil gaya tarik-tekan struktur portal bangunan OBI Campus ini diperoleh dari software app Frame Design 2D.

\subsection{SAMBUNGAN-SAMBUNGAN}

Sambungan Kolom ke Pondasi

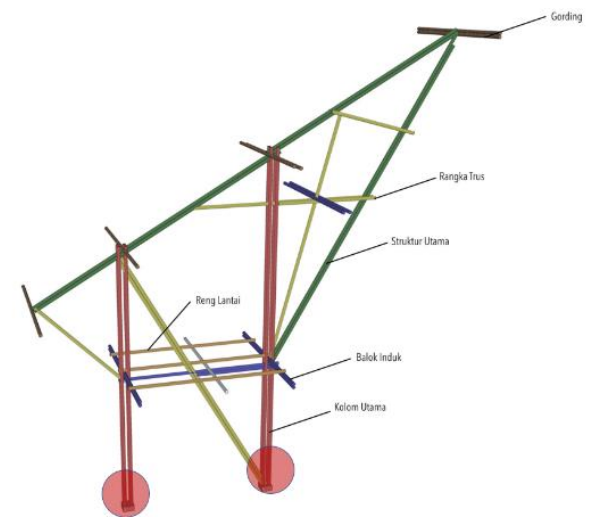

Figur 7. Letak Sambungan 1 (Kolom - Pondasi)

Sambungan ini merupakan sambungan yang menyatukan seluruh struktur portal bangunan dengan pondasi pedestal bangunan. Pada 1 portal bangunan terdapat 4 buah pedestal yang berbentuk persegi empat. Kolom utama pada portal ini berjumlah 4 buah yang tiap kolomnya memiliki 4 buah bambu yang kemudian dimasukan / di cor kedalam pedestal beton tersebut. Bambu yang digunakan pada kolom tersebut merupakan bambu yang berjenis bamboo petung. 

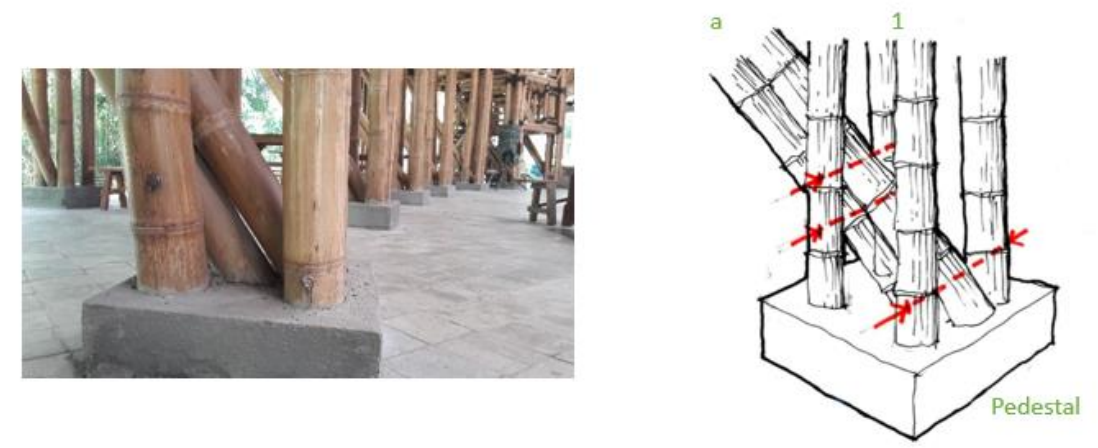

Figur 8. Sambungan 1

Sambungan no 1 merupakan sambungan yang menghubungkan beban seluruh bangunan kepada pondasi bangunan. Sambungan ini berupa kolom utama bangunan yang dimasukan / dicor ke dalam pedestal beton. Batang pengaku diagonal juga dicor ke dalam pedestal beton kemudian di mur baut ke kolom utama bangunan.

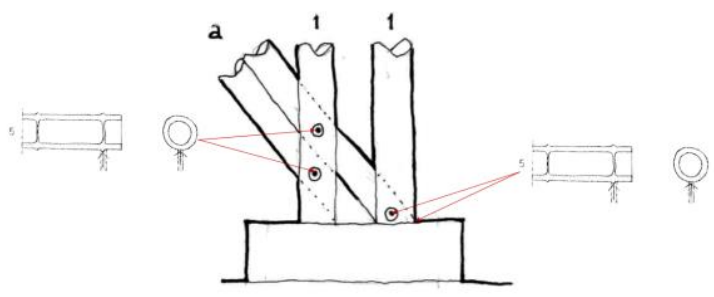

Figur 9. Jenis Sambungan pada Sambungan 1

Ada 2 jenis sambungan pada tipe yaitu, sambungan dimana batang bambu dicor ke dapat pedestal beton dan sambungan dimana bambu dijepit kemudian di mur baut. Kedua tipe sambungan ini dikategorikan menjadi 1 jenis yaitu sambungan gabungan dari jenis 5 yaitu bambu disambungan dengan sambungan tegak lurus serat bambu.

\section{ANALISIS GAYA PADA TIAP MUR-BAUT PADA SAMBUNGAN 1}

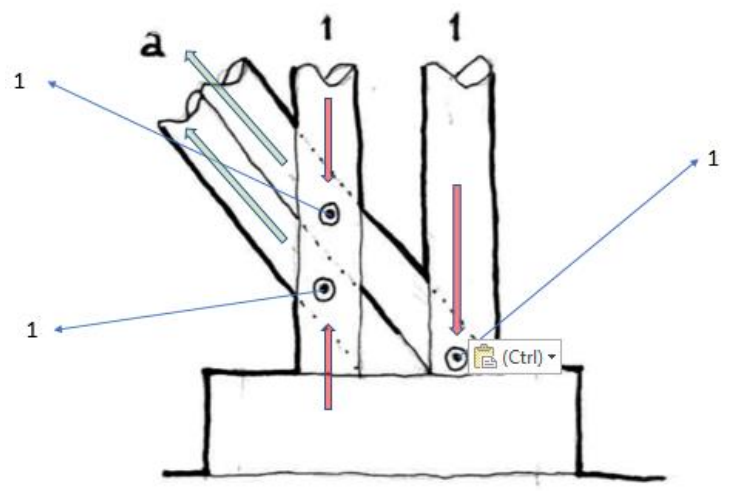

Figur 10. Letak Mur-Baut pada Sambungan 1 
Ada 1 buah jenis sambungan Mur-Baut yang terdapat pada sambungan 1 yaitu sambungan mur-baut yang terletak tegak lurus pada batang bambu (Sambungan Jenis 5). Ketiga sambungan tersebut mendapat gaya yang sama yaitu gaya tarik dari batang a dan tekan dari batang 1 .

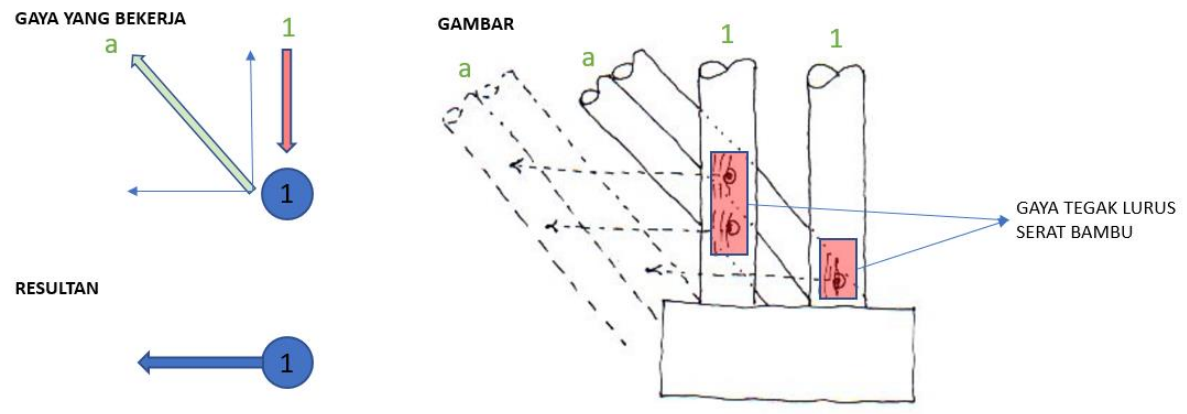

Figur 11. Analisa Vektor Sambungan 1

Dari hasil Analisa gaya yang dilakukan pada sambungan 1, gaya akhir yang terjadi pada sambungan tersebut merupakan gaya ke arah kiri (lihat pada gambar). Gaya tersebut gaya terjadi tegak lurus serat bambu pada batang bambu. Gaya mur-baut yang merupakan gaya tegak lurus dari batang bambu dapat menyebabkan cracking / penyet pada batang bambu.

\section{KESIMPULAN DAN SARAN PADA SAMBUNGAN 1}

Sambungan 1 tidak memiliki tambahan pengikatan ijuk (Sambungan Jenis 3) karena Sambungan 1 sudah cukup stabil dengan tidak adanya pengikatan. Sambungan pada batang bambu 1 dan batang bambu a keduanya telah dikakukan oleh beton dari pedestal. Gaya yang bekerja pada mur baut sambungan ini merupakan gaya yang tegak lurus serat bambu sehingga kerusakan yang terjadi tidak fatal.

\section{SAMBUNGAN KOLOM DAN STRUKTUR UTAMA}

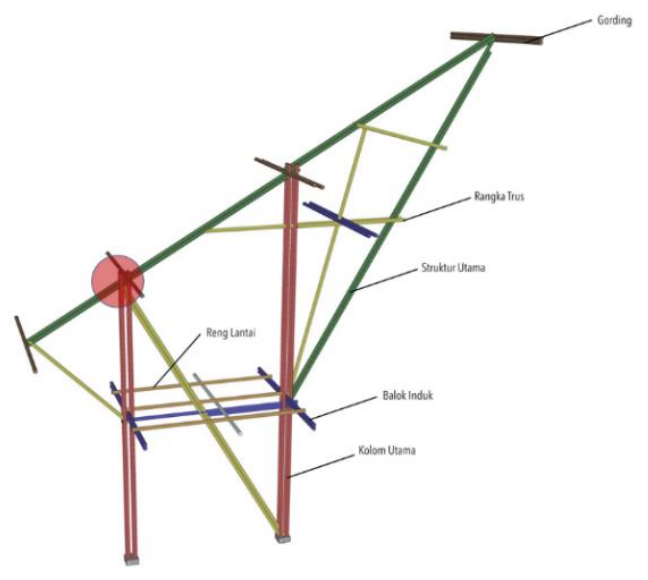

Figur 12. Sambungan 2 (Kolom -Struktur Utama)

Sambungan ini terletak pada bangunan bagian atas. Sambungan ini merupakan sambungan pertemuan antara struktur portal bangunan dengan gording atap bangunan. 
Sambungan ini jga merupakan pertemuan dari kolom utama, batang struktur utama, dan batang pengaku.
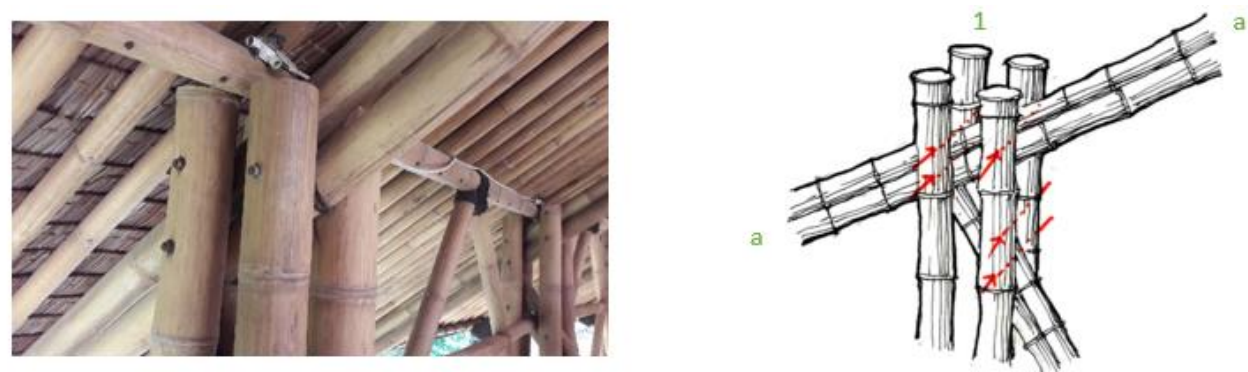

Figur 13. Sambungan 2

Sambungan no 2 merupakan sambungan pertemuan dari batang no 1, 2, batang pengaku a. Pada batang sambungan antara batang bambu 1 dengan batang bamboo 2 disambungkan dengan cara di mur baut satu bambu kepada bambu lainnya dan pada sambungan batang bambu 1 dengan batang pengaku a disambungan dengan pembuatan fish mouth joint pada batang bambu a kemudian disambungkan ke batang bambu a.

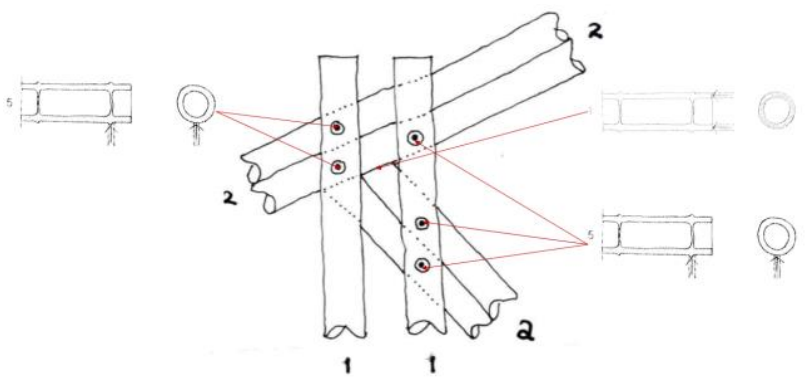

Figur 14. Jenis Sambungan pada Sambungan 2

Ada 2 jenis pada sambungan ini yaitu dimana batang kolom utama/batang 1 menjepit batang 2 lalu di mur baut, batang kolom utama/batang 1 menjepit batang pengaku a, dan $\mathrm{T}$ Joint pada batang 2 dengan batang pengaku a. Sambungan batang kolom utama / batang 1 menjepit batang 2 lalu di mur baut, batang kolom utama / batang 1 menjepit batang pengaku a kemudian di mur baut dikategorikan menjadi sambungan jenis 5 yaitu dimana sambungannya diletakan tegak lurus serat kemudian sambungan T Joint pada batang 2 dengan batang pengaku a merupakan sambungan jenis gabungan dari sambungan jenis 1 (Fish mouth Joint) dan 5.

\section{ANALISA GAYA PADA TIAP MUR-BAUT PADA SAMBUNGAN 2}




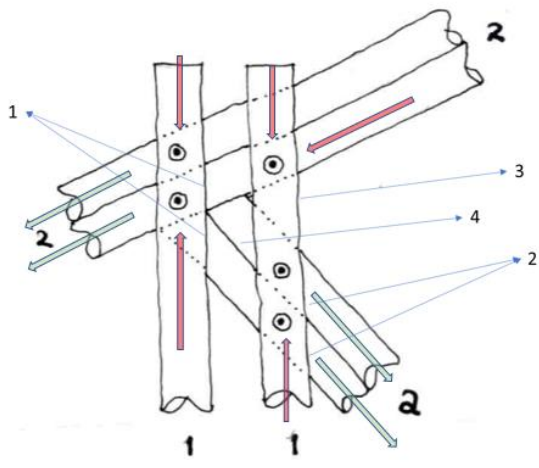

Figur 15. Letak sambungan dan Gaya yang bekerja pada sambungan 2

Sambungan 2.4 merupakan sambungan yang menyatukan batang bambu 2 dengan batang pengaku a. Sambungan ini merupakan sambungan berjenis sambungan fish mouth joint, dengan batang bambu a diukir menyerupai mulut ikan kemudian ditempelkan pada batang bambu 2. Gaya yang bekerja pada sambungan ini merupakan gaya kebawah (lihat gambar). Dengan sifat kedua batang bamboo merupakan bersifat tarik sehingga gaya lateral masingmasing batang bambu menjadi ditiadakan sehingga hanya terdapat gaya aksial pada batang bambu.

\section{KESIMPULAN DAN SARAN PADA SAMBUNGAN 2}

Sambungan 2 merupakan sambungan yang cukup stabil apabila dilihat dari analisa gaya yang terjadi. Gaya yang menyebabkan batang struktur utama (batang 2) melendut dikakukan oleh batang pengaku a sehingga meminimalkan kerusakan pada batang bambu yang diakibatkan oleh gaya yang sejajat serat batang bambu pada batang kolom utama (batang 1) dan batang struktur utama (batang 2).

\section{SAMBUNGAN 3}

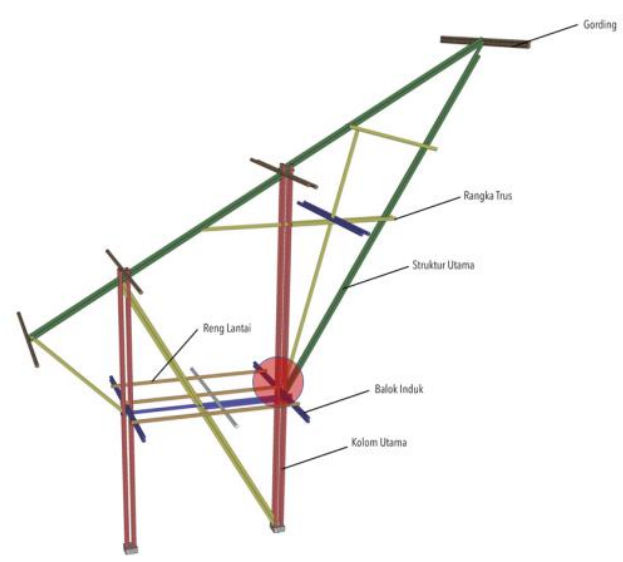

Figur 16. Letak Sambungan 3 ( Kolom - Mezzanine - Struktur Utama) 

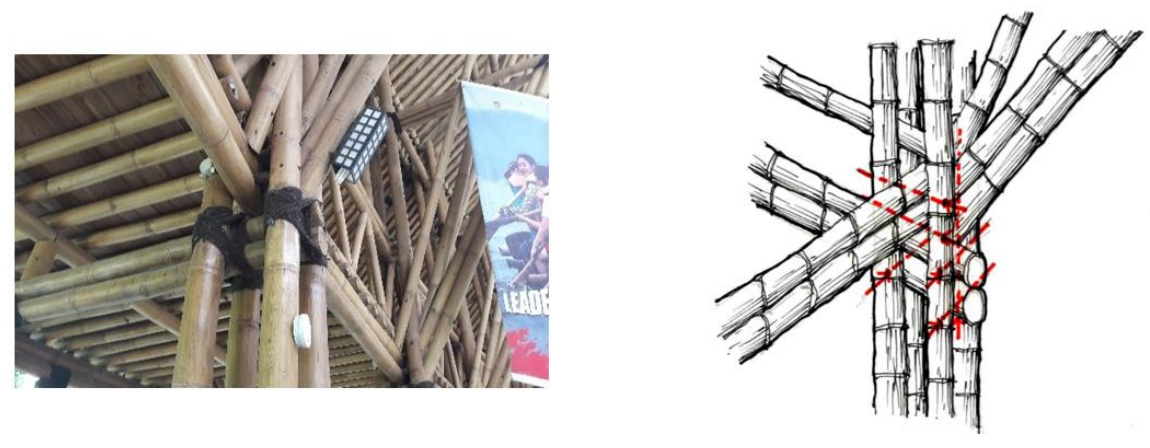

Figur 17. Sambungan no 3

Sambungan no 3 merupakan sambungan yang menyatukan batang utama 1,3, dan batang pengaku d. Sambungan ini juga merupakan sambungan yang menyambungkan struktur batang balok induk dari lantai mezzanine. Sambungan ini disambung dengan cara di mur-baut satu sama lain dan kemudian diikat.

Ada 2 sambungan yang terdapat pada sambungan ini yaitu sambungan batang 3 dan batang $\mathrm{d}$ kepada batang balok induk $\mathrm{f}$ dan sambungan batang 1 dengan batang 3 , batang $\mathrm{d}$, batang $\mathrm{g}$, dan batang $\mathrm{f}$.

Sambungan batang 3 dan batang d kepada batang balok induk $\mathrm{f}$ merupakan tergolong sambungan gabungan dari sambungan jenis 1 (sambungan yang merupakan kontak langsung dari permukaan bambu) dan kemudian disatukan dengan sambungan jenis 5 (disatukan dengan mur-baut yang diletakan tegak lurus serat).

Sambungan batang 1 dengan batang 3 , batang d, batang g, dan batang f merupakan tergolong sambungan jenis 5 dimana sambungannya diletakan tegak lurus serat bambu. Sambungan jenis 3 (sambungan dari permukaan luar bambu) yang berupa ikatan ijuk juga digunakan untuk memperkuat sambungan ini.

\section{ANALISA GAYA PADA TIAP SAMBUNGAN PADA SAMBUNGAN 3}

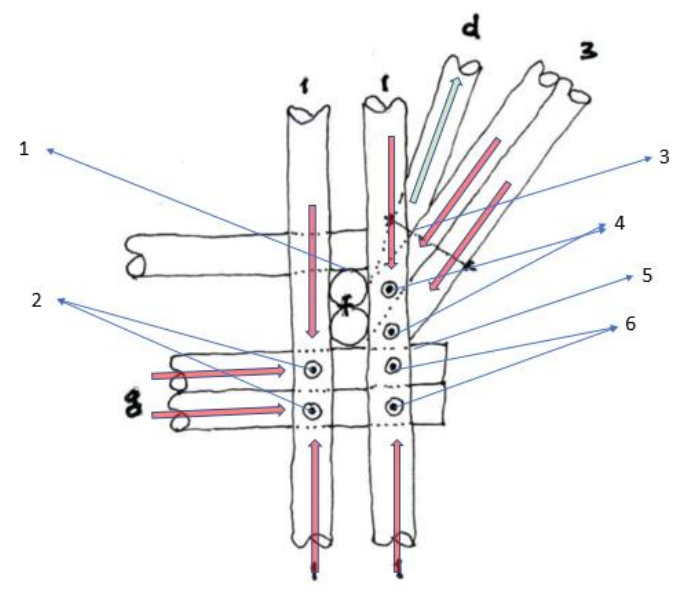

Figur 18. Letak Mur Baut dan Sambungan pada Sambungan

Ada berbagai macam sambungan yang terdapat pada sambungan 3. Sambungansambungan tersebut bervariasi dari sambungan mur-baut yang diikat hingga sambungan fish mouth joint/ T joint. Sambungan-sambungan tersebut dapat dibagi menjadi 6 buah sambungan. 
Sambungan 3 merupakan sambungan yang cukup penting pada struktur bangunan ini dikarenakan sambungan ini merupakan pertemuan banyak batang struktur utama (batang 1 dan batang 3), batang struktur lantai mezzanine (batang $\mathrm{g}$, batang $\mathrm{f}$, dan reng lantai bambu), dan batang pengaku d. Sambungan ini merupakan sambungan terakhir dan pertemuan dari bebanbeban sebelum mencapat pondasi bangunan.

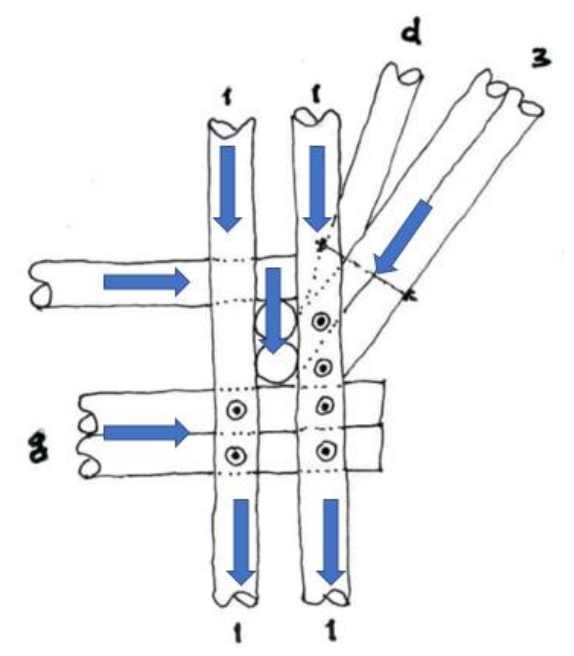

Figur 19. Penyaluran Beban pada Sambungan 3

Akibat beberapa dari sambungan kurang stabil menyababkan sambungan ini memiliki tambahan pengakuan sambungan yang berupa pengikatan. Pengikatan sambungan ini diterapkan pada sambungan 3.2 dan sambungan 3.6.

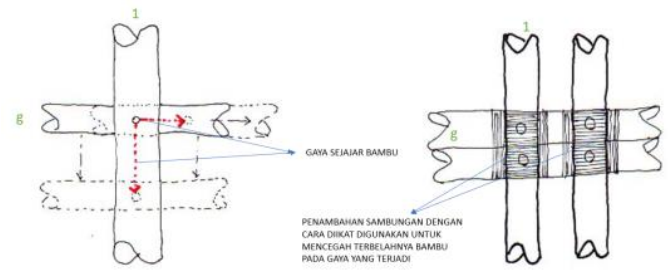

Figur 20. Pengikatan pada Sambungan Kolom dan Balok Lantai Mezzanine

Pengikatan batang bambu dilakukan dengan arah tegak lurus serat bambu batang bambu. Bahan yang dapat digunakan untuk mengikat batang-batang bambu tersebut adalah tali ijuk yang juga dapat ditemui dan sengaja di tanam diarea OBI Campus. Selain pengikatan, cara lain yang dapat dilakukan untuk menguatkan batang bambu adalah diberikan klem dan juga dapat digunakan pengisian mortar pada batang bambu yang kurang stabil. 


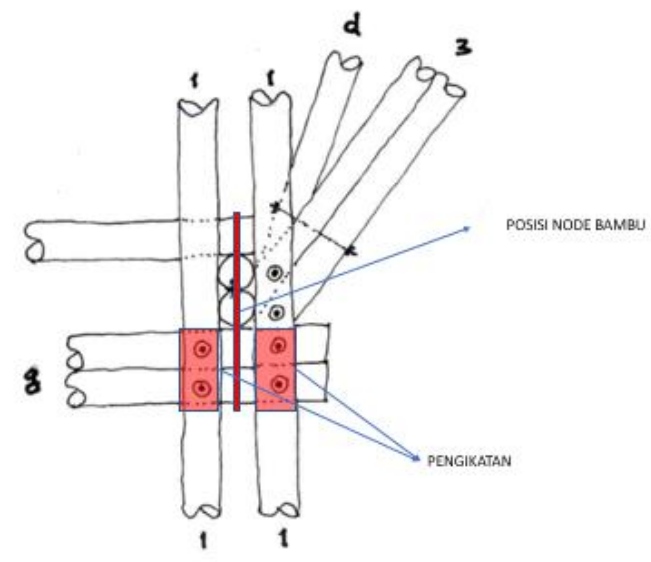

Figur 21. Penguatan pada beberapa sambungan pada Sambungan 3

\section{SAMBUNGAN PENGAKU}

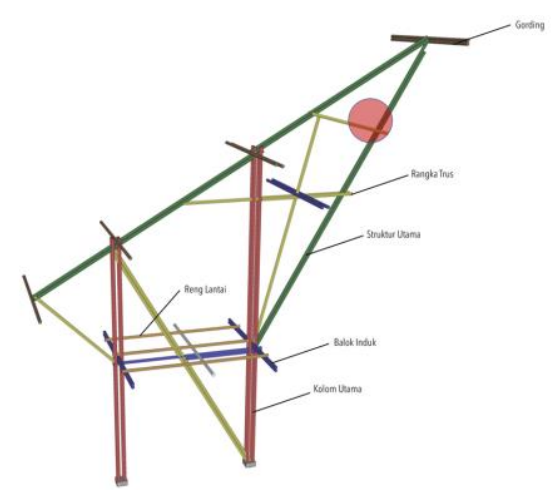

Figur 22. Letak Sambungan $\mathrm{g}$

Sambungan g merupakan sambungan yang terletak di tengah-tengah batang struktur utama (batang 3). Sambungan ini merupakan salah satu sambungan yang digunakan untuk mengakukan batang struktur utama (batang 3). Batang 3 yang merupakan struktur utama dikakukan dengan cara dijepit oleh batang e sehingga batang 3 tidak mengalami lendutan.
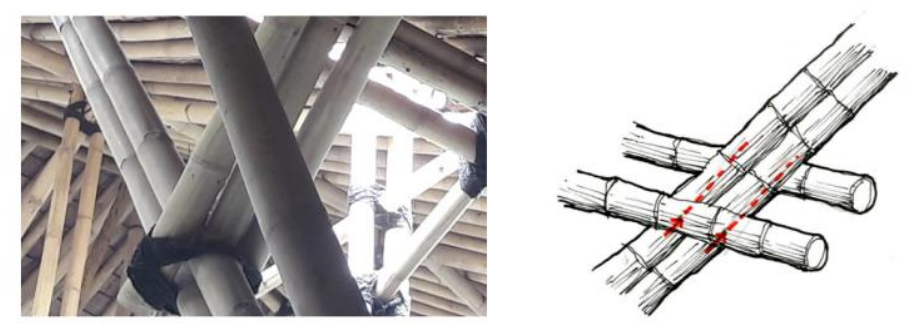

Figur 23.Sambungan $g$ 


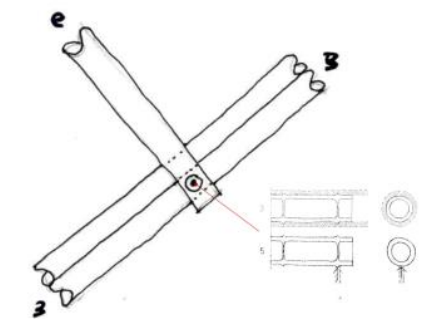

Figur 24. Klasifikasi Sambungan pada Sambungan g

Sambungan pada sambungan g merupakan sambungan mur baut yang berjumlah 2 buah. Sambungan ini merupakan sambungan mur-baut 3 lapis. Sambungan ini merupakan gabungan dari 2 kategori yaitu kategori 5 (mur-baut yang diletakan tegak lurus serat bambu) dan kategori 3 (pengikatan tali ijuk pada sambungan).

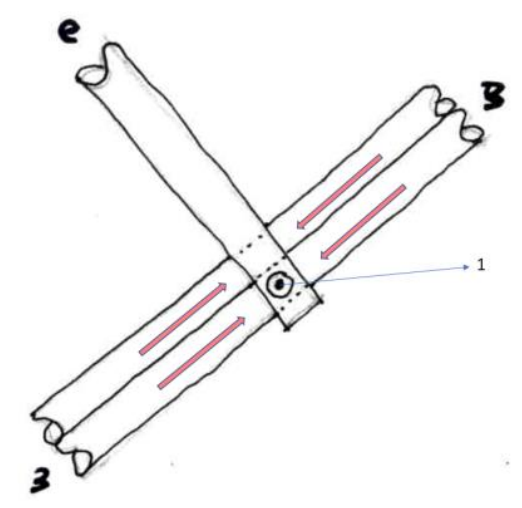

Figur 25. Gaya yang Bekerja pada Sambungan g

Sambungan g merupakan sambungan pertemuan antara batang struktur utama (batang 3) yang dijepit dengan batang pengaku (batang e). Gaya yang bekerja pada batang 3 adalah gaya tekan sedangkan gaya yang bekerja pada batang c merupakan netral. Batang c digunakan untuk mengakukan batang 3 . 


\section{SAMBUNGAN G}
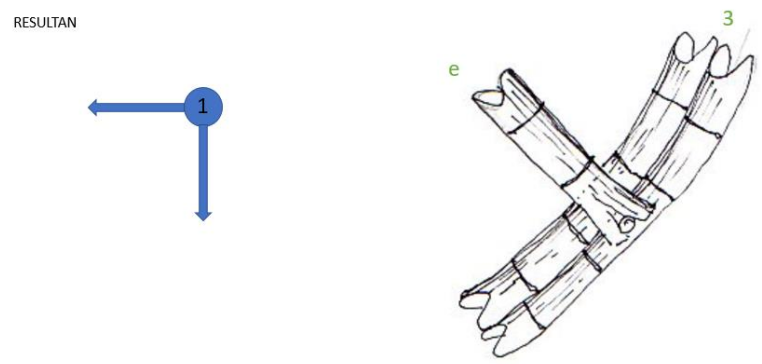

Figur 26. Analisa Vektor Sambungan g

Berdasarkan analisa veKtor yang dilakukan gaya akhir yang terjadi merupakan gabungan gaya aksial dan lateral yang menyebabkan batang 3 (batang struktur utama) menjadi lendut sehingga menyebabkan terjadinya kerusakan sejajar serat bambu yang menyebabkan batang e dapat terjadi splitting / batang bambu terbelah sehingga penambahan kekuatan sambungan dapat dilakukan dengan memberikan penguatan yang berupa pengikatan ijuk pada sambungannya.

\section{KESIMPULAN DAN SARAN PADA SAMBUNGAN 3}
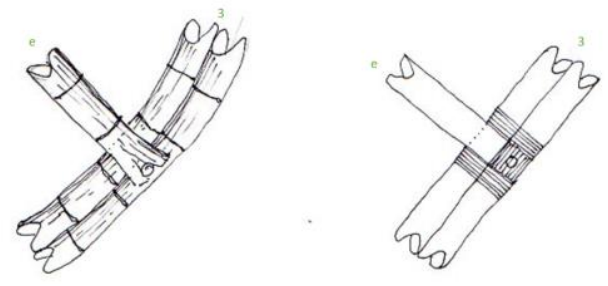

Figur 27. Pengikatan pada sambungan $g$

Batang c yang berfungsi untuk mencegah menlendutnya batang 3 harus diberikan tambahan penguatan yaitu dapat berupa pengikatan. Hal ini disebabkan karena gaya yang bekerja pada batang 3 kurang dapat secara baik ditahan apabila hanya dengan sambungan murbaut.

\subsection{LABORATORIUM EKSPERIMENTAL SAMBUNGAN MUR-BAUT DAN KOMBINASINYA}

Sistematika tes tumpu ini dilakukan dengan cara memotong bambu yang berukuran kurang lebih $8 \mathrm{~cm}$ dengan panjang $8 \mathrm{~cm}$ dan memiliki ketebalan kurang lebih $1 \mathrm{~cm}$. Bambu tersebut kemudian dibuat ukiran diatasnya berbentuk setengah lingkatan dengan diameter $1 \mathrm{~cm}$ (sesuai dengan besar dari mur-baut). Bambu-bambu tersebut dibuat dengan jumlah 5 buah dengan diberikan perkuatan yang berbeda-beda. Bambu tersebut ditekan menggunakan mesin (lihat pada gambar) sampai mur-baut tersebut masuk ke dalam bambu. Bambu yang digunakan pada percobaan ini merupakan Bambu Tali/Apus. 


\section{TANPA PERKUATAN}
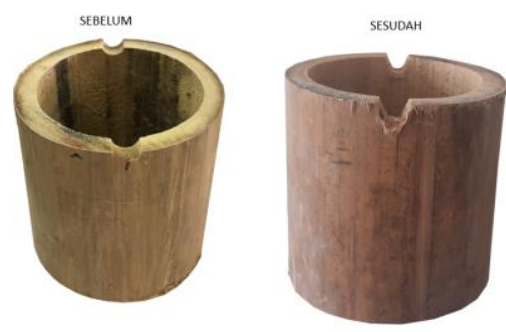

Figur 28. Tes tumpu mur-baut tanpa perkuatan

Tes pertama yang dilakukan adalah melihat kerusakan yang terjadi pada batang bambu apabila tidak diberikan perkuatan. Pada gambar dapat dilihat akibat tidak diberikan perkuatan batang bambu ternyata mengalami kerusakan yaitu splitting/terbelah. Percobaan ini dapat dijadikan sebuah acuan terhadap percobaan lainnya yang memiliki perkuatan.

Hasil pada uji tes tumpu bambu tanpa perkuatan menunjukan bahwa bambu tanpa perkuatan dapat menahan beban hingga $6 \mathrm{kN}$ sebelum mulai membelah serat bambu.

\section{DENGAN PERKUATAN NODE BAMBU}
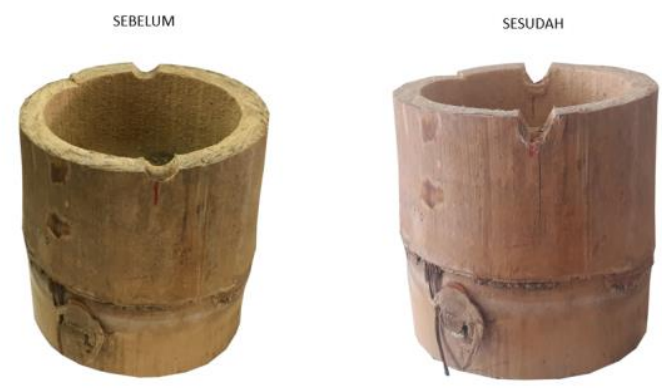

Figur 29. Tes tumpu mur-baut dengan perkuatan Node Bambu

Tes ini merupakan tes mur-baut dengan perkuatan alami yaitu dengan peletakan node bambu dekat dengan sambungan mur-baut. Kerusakan sejajar serat yang dialami bambu dengan node ini ternyata masih terjadi. Kerusakan tersebut dapat dilihat melewati node bambu tersebut.

Hasil pada uji tes tumpu bambu dengan perkuatan node menunjukan bahwa bambu perkuatan node dapat menahan beban hingga $6 \mathrm{kN}$ sebelum mulai membelah serat bambu. 


\section{DENGAN PERKUATAN KLEM}
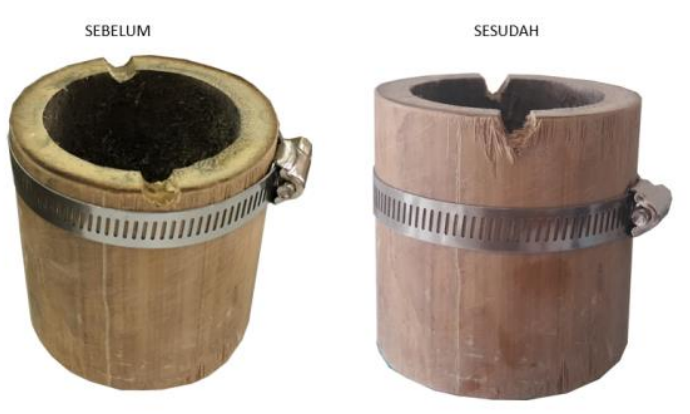

Figur 30. Tes tumpu mur-baut dengan perkuatan Klem

Klem merupakan material yang cukup mudah ditemui di toko alat bangunan dengan harga yang cukup murah. Klem juga dapat digunakan sebagai alat untuk perkuatan bambu terhadap gaya mur-baut yang sejajar serat bambu. Jika dilihat pada gambar diatas ternyata kerusakan pada gaya sejajar serat tidak terjadi pada samungan klem. Mur-baut masuk kedalam batang bambu tanpa membelah bambu.

Hasil pada uji tes tumpu bambu dengan perkuatan klem menunjukan bahwa bambu perkuatan klem dapat menahan beban hingga $7 \mathrm{kN}$ sebelum mulai membelah serat bambu.

\section{DENGAN PERKUATAN PENGIKATAN TALI IJUK}

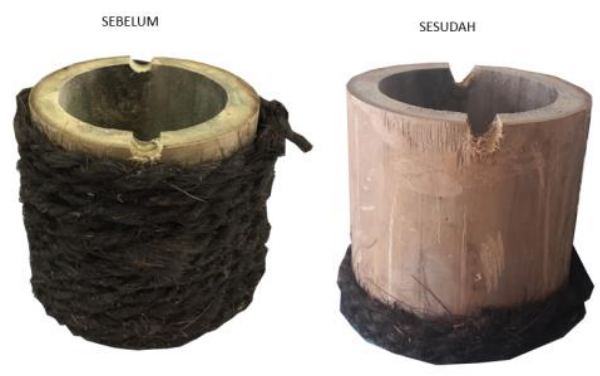

Figur 31. Tes tumpu mur-baut dengan perkuatan Tali Ijuk

Tali Ijuk merupakan perkuatan yang digunakan pada bangunan OBI Campus terhadap gaya yang sejajar serat. Pada sambungan ini kerusakan yang terjadi pada gaya sejajar serat cukup sedikit. Tali ijuk ini juga merupakan material yang mudah di dapat dan sangat terjangkau sehingga pemakaian tali ijuk sangat sering digunakan pada sambungan bangunan bambu.

Hasil pada uji tes tumpu bambu dengan perkuatan ikatan menunjukan bahwa bambu perkuatan ikatan dapat menahan beban hingga $6.3 \mathrm{kN}$ sebelum mulai membelah serat bambu. 


\section{DENGAN PERKUATAN MORTAR}
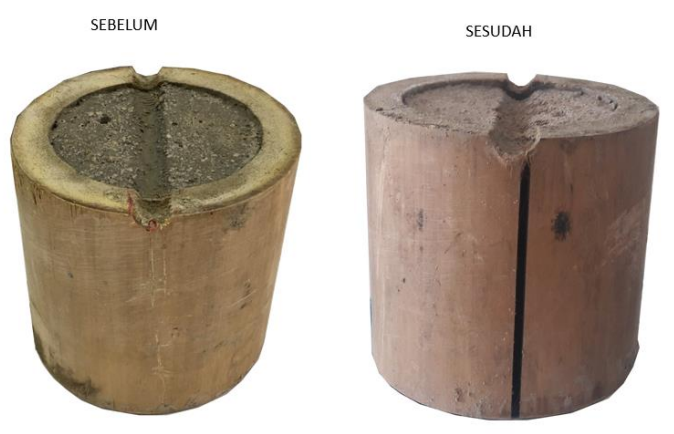

Figur 32. Tes Tumpu mur-baut dengan perkuatan mortar

Dengan pengecoran mortar membuat sambungan bambu ini lebih berat dibandingkan perkuatan yang lainnya. Pada pengetesan mortar dibuat dua buah jenis yaitu yang berumur 1 hari dan yang berumur 3 hari.

Hasil pada uji tes tumpu bambu dengan perkuatan pengecoran menunjukan bahwa bambu perkuatan pengecoran dapat menahan beban hingga $7 \mathrm{kN}$ sebelum mulai membelah serat bambu.

Dengan durasi 3 hari kekuatan pada mortar tenyata bertambah cukup banyak, mortar yang sudah berusia 3 hari mampu menahan beban hingga $12.5 \mathrm{kN}$. Meskipun kekuatan untuk menahan gaya sejajar bambu yang cukup baik namun mortar menyebabkan sambungan menjadi sangat berat sehingga menambah beban kepada sambungan lain yang merupakan arah penyaluran bebannya.

\section{KESIMPULAN}

Pengikatan sambungan hanya dilakukan pada sambungan dengan gaya mur-baut yang memiliki gaya yang sejajar serat bambu. Sambungan-sambungan yang memiliki gaya sejajar bambu merupakan sambungan-sambungan antara balok lantai dengan kolom (dikarenakan pada sambungan tersebut memiliki gaya aksial dan lateral murni yang secara vektor tidak stabil) dan sambungan-sambungan dari batang pengaku terhadap batang struktur utama yang secara analisa vektor juga tidak stabil sehingga menyebabkan Bamboo Splitting.

Penanggulangan kerusakan pada sambungan-sambungan di struktur portal truss pada bangunan "The Great Hall" sudah dilakukan, sambungan-sambungan yang memiliki gaya yang merusak bambu sejajar dengan serat bambu telah diberikan penguatan tradisional dengan cara pengikatan dengan ijuk, namun seiring perkembangan jaman perkuatan sambungan dapat dilakukan dengan cara yang lebih bermacam-macam lagi.

Pada percobaan tes uji tumpu sambungan ternyata dapat pengikatan sambungan dapat digantikan dengan beberapa sambungan lainnya. Pengantian perkuatan sambungan menjadi klem memiliki performa sambungan yang lebih baik dari pengikatan dan juga dapat memberikan kesan modern pada bangunan. Dengan pengecoran kekuatan pada sambungan jauh lebih kuat daripada kelm maupun pengikatan namun pengecoran pada sambungan merupakan sambungan yang jauh lebih berat daripada pengikatan maupun klem sehingga lebih cocok diletakan area yang mendekati pondasi bangunan. 


\section{DAFTAR PUSTAKA}

Frick, Heinz. (2004). Ilmu Konstruksi Bangunan Bambu: Pengantar Konstruksi Bambu. Yogyakarta: Kanisius.

Janssen, J. J. (2000). Designing Building with Bamboo. INBAR Technical Report No. 20. Beijing: International Network for Bambooand Rattan (INBAR)

Krisanti, Janice. (2013). Relasi Bentuk dan Struktur pada Bangunan Bambu Bentang Besar:

"The Great Hall”, OBI Eco-Campus, Jatiluhur. Skripsi tidak diterbitkan. Bandung: Universitas Katolik Parahyangan.

Widyowijatnoko, Andry. (2012). Traditional and Innovative Joints in Bamboo Construction. Aachen : RWTH Aachen.

Dunkelberg, Klaus (1985). Bamboo as a Building Material. Stuttgart 